\title{
Dark Future for Czechoslovakia: American and Polish Diplomats during the Munich Crisis ${ }^{1}$
}

The theme "Munich 1938" still attracts the attention of historians and there are still gaps in our knowledge that need to be filled in, despite a rich bibliography on the dramatic events in Czechoslovakia and their international context. Particularly, Czechoslovak-British relations have been researched in depth and several quality monographs have been published in recent years. The same applies to Czechoslovak-French relations. ${ }^{2}$ Relations between the United States and Czechoslovakia, particularly diplomatic relations, do not have a similarly rich bibliography yet, with the exception of works by the author of this article and a few titles by other authors.

A phenomenon traditionally and simply named the "Munich betrayal" or simply "Munich" has became even a terminus technicus of other disciplines besides history - particularly in political science and international relations.

1 This publication was created with the financial support of the Anglo-American University project No. AAU-2018-1.

2 Smetana Vít, In the Shadow of Munich. British Policy towards Czechoslovakia from the Endorsement to the Renunciation of the Munich Agreement (1938-1942), Prague, Karolinum 2008; Dejmek Jindřich, Czechoslovak Foreign Policy and the Search for Security in Central Europe between the World Wars (A Survey of Basic Problems). Historia Europae Centralis, 1998, 107145; Dejmek Jindřich, Československo-britské politické vztahy v rámci locarnského bezpečnostního systému (1925-1936), Moderní dějiny, 1998, 7-97 and a number of studies by this author including Dejmek Jindřich, Britský appeasement: bilance půlstoletí trvající historiografické diskuse, Český časopis historický, 2000/1, 130-142. Dejmek Jindřich, Československo, jeho sousedé a velmoci ve XX. Století (1918-1992). Vybrané kapitoly z dějin československé zahraniční politiky, Praha: Centrum pro ekonomiku a politiku, 2002; Lacaze, Yvon, La France et Munich: étude d'un processus décisionnel en matiere de relations internationales, Berne: Peter Lang, 1992 and numerous other works of this author; Kubů Eduard, Československo-francouzská spojenecká smlouva a Německo. I. Ohlas a př́ípravy k podpisu dokumentu (do března 1924), Historie a vojenství, 2000/2, 266-293; Břach Radko, Spojenecká smlouva mezi Československem a Francií z 25. ledna 1924 a garanční dohoda čs. - francouzská z 16. ř́jna 1925, Historie a vojenství 43, 1994/6, 3-21; Wandycz Piotr, The Twilight of French Eastern Alliances, 1926-1936: French-Czechoslovak-Polish Relations from Locarno to the Remilitarization of the Rhineland, Princeton, N.J.: Princeton University Press, 2014. 
Ministers of foreign affairs received in 1938 daily avalanches of reports, despatches, memoranda of conversation and verbal notes in which their diplomats described, analyzed and expressed their views on the escalating security situation in Central Europe. The main source of information were diplomatic missions in Prague and Berlin and other main European capitals from where the diplomats reported often several times per day. They informed of not only what they had learned from their Czechoslovak counterparts, but they tried to get reliable information from presidents, prime ministers, ministers of foreign affairs, politicians, and journalists in the country of their accreditation. In the dramatic days of September 1938 they requested daily appointments with leading politicians and sometimes met them even repeatedly in one day. The diplomats also met each other frequently hoping to learn "something" and, as was the case with many, to get an assurance that the situation was not that hopeless. The diplomats at the time witnessed situations and the behavior of many politicians and diplomats which in peaceful times rarely happened or did not happen at all - they saw exhaustion, fatigue, anxiety and despair or, on the other hand, a false optimism just barely disguising nervousness and helplessness. Czechoslovak diplomats were targets of inquiry everywhere around the world. The interest in these conversations was mutual - the Czechoslovak diplomats hoped to get support for their country.

Another feature of the information activity of those days was an abundance, even surplus of conditional sentences and "ifs". Diplomatic language is a typical area for this, but during the Munich crisis their usage reached an extreme frequency. This was a sign of uncertainty and unwillingness to express a firm, determined position. Very typical was what the British Envoy in Prague sir Basil Cochran-Newton said, that "he was by no means pessimistic but on the other hand was not warranted in expressing optimism." ${ }^{3}$

The goal of this article is to examine - from the Anschluss of Austria on 12 March 1938 to the Conference in Munich on 29-30 September 1938 the positions, actions, and reports of American diplomats in selected European capitals - in Prague, London, and Paris - with particular attention to the reports on relations between Czechoslovakia and Poland.

As there is an abundance of documents from these dramatic days, this article cannot be more than just a survey study of selected diplomatic documents, but the author hopes that this study will be a telling contribution to the diplomatic history of events clearly leading to World War II. ${ }^{4}$

\footnotetext{
3 Foreign Relations of the United States (henceforth FRUS), 1938/I, 552.

4 This article uses also sources collected for my monograph Polišenská, Milada, Diplomatické vztahy Československa a USA 1918-1968, Volume I/1, 1918-1938, Ministerstva, legace a diplomaté, Praha: Libri, 2012, and I/2, Priority, diplomatická praxe a politický kontext, Praha: Libri, 2014.
} 


\section{Prague: Wilbur John Carr, American Envoy}

The American Envoy in Prague during the Munich crisis and the last Envoy in Prague before the occupation was Wilbur John Carr (1870-1942). He was a very experienced and respected high official of the State Department ${ }^{5}$ serving for many years as Director of the Consular Service and subsequently, from 1924 to 1937, as Assistant Secretary of State. His assignment to Prague from 13 July 1937 to 6 April 1939 was his first and last foreign mission.

Carr's reports reflect the skills and capacities of an experienced, knowledgeable diplomat and a good observer. He made trips to the Sudeten area where he personally collected information from locals and paid attention also to the moderate and anti-Nazi environment in the Sudeten area. Carr's reports demonstrated a sense of proportion and objectivity. He always used as many sources as he could - he maintained numerous contacts, had his own sources of information, shared information, and discussed the Sudeten crisis issues with other diplomats in Prague while prominent attention was paid to the views of the British Envoy Basil Cochran Newton, French Envoy Leopold Victor de Lacroix, German Envoy Ernst Eisenlohr, Hungarian Envoy János Wettstein, and Polish Envoy Kazimierz Papée $^{6}$ who understood and wrote in favor of Czechoslovakia in the Sudeten crisis but naturally protested against Czechoslovak anti-Polish steps resulting from the Teschen tension. Carr also shared information with his American colleagues in Berlin, Warsaw, Budapest, London, Paris, and other U.S. missions which might have been interested. However, it seems that the U.S. Ambassadors and Envoys in those places did not use it. This is obviously a pity as the voice of their colleague reporting directly from the center of events should certainly have had significant weight.

The American Legation in Prague produced thus a large number of reports and information on various aspects of the security situation in Czechoslovakia. All staff of Legation, both diplomats and consular officers, were extremely busy and worked under great pressure. In days when the situation changed hour

\footnotetext{
5 Willbur J. Carr concentrated his career on service within the Department of State, being instrumental for its deep transformation. His name is associated particularly with his work of many years leading to the adoption of the Rogers Act (1924) which built a unified United States Foreign Service and introduced an admission examinitation system, promotion by merit and other important reforms. He was nicknamed the Father of American Foreign Service or one of the three Great Civil Servants.

${ }^{6}$ Kazimierz (Casimir) Papée (1889-1979) was Polish envoy in Prague from 1938, serving previously at several diplomatic posts in Europe and in the Polish Foreign Ministry. After the occupation of Czechoslovakia by Nazi Germany in 1939, he became Polish Ambassador to the Holy See where he tried vainly to achieve Pope Pius XII's condemnation of Nazi atrocities on Polish territory. After the war, in 1958, Pope John XXIII revoked his accreditation in order to stabilize relations with Poland. Papée lived until his death in exile in Rome.
} 
by hour, Carr sent his reports, even if they had become rather long, to Washington telegraphically.

Just a few examples of Carr's reports. On 10 April 1938 Carr sent Washington a comprehensive report, The Political Situation in Czechoslovakia. U.S. diplomats had obviously talked to officials of the political Leadership of the Sudetendeutsche Partei (SdP) and inquired about the participation of Sudeten Germans in foreign politics and arms control, but received only "diplomatic answers" from them. Carr wrote that there were doubts about the positive prospects of a solution of the Czechoslovsk situation, that most Sudeten Germans were very impressed by Hitler's success in Austria (i.e. the Anschluss of Austria by Germany), and that they would most likely claim the incorporation of Sudeten area into the Reich. ${ }^{7}$

25 April 1938 Carr summarized Konrad Henlein's Eight Points - eight conditions presented to the Czechoslovak Government by the Carlsbad congress of the Sudetendeutsche Partei which were based on consultations with the party leader Konrad Henlein with Hitler in March. ${ }^{8} 5$ May 1938 Carr informed about the current Slovak efforts to achieve autonomy but he was wrong in his assumption that the tense situation in Central Europe would rather unify the Czechs and Slovaks. ${ }^{9} 8$ May, Carr telegraphed about the efforts of the Czechoslovak government, with the help of the media, to keep calm in the country but, despite that, incidents occured in which both Germans and Czechs took part. The Government took reasonable measures but the Germans saw them as persecution, and their interpretation abroad would be certainly exaggerated, as Carr rightly expected. He noticed prevailing feelings of anxiety in the country and speculation in governmental circles about the Soviet position. 9 June 1938 Carr provided the State Department an in-depth report on Konrad Henlein. ${ }^{10} \mathrm{He}$ included also information from the Czechoslovak Envoy in Great Britain Jan Masaryk on Henlein's Janus-faced behavior. Masaryk said that Henlein played in London the role of a loyal Czechoslovak citizen, but in Czechoslovakia his behavior was incompatible with loyalty to his state.

Prague became during the culminating Sudeten crisis an intersection of journalists and reporters of all leading press agencies and Carr did not neglect to meet with journalists. Marcel William Fodor ${ }^{11}$ was a noted journalist at that time

\footnotetext{
7 National Archive, College Park, M.D., U.S.A., (henceforth NARA), 860F.00/484.

8 NARA, 860F.00/477.

9 NARA, 60F.00/482.

10 NARA, 860F.00/ illegible.

11 Marcel William Fodor (1890-1977), Hungarian journalist, Central European correspondent of Manchester Guardian from 1920 to 1938. After Anschluss he left in Spring 1938 Austria and spent several months in Czechoslovakia and then via Great Britain reached the United States (1940-1944). After the World War II he worked for the American administration in Germany and from 1955 for the Voice of America.
} 
who interviewed on 12 June Karl Hermann Frank. ${ }^{12}$ Right afterwards, the journalist informed Carr and Carr sent a report to the Department of State. Carr also described the Sudeten German requirements and noticed that the Czechoslovak Government was then making all efforts to communicate the information on negotiations to all levels of society, as governmental officials were being criticized that the public was not informed on a daily basis about the status of talks. Carr also knew that Henlein was in Germany these days and that he had had three meetings with Hitler. ${ }^{13}$

On request of Ferdinand Veverka, former Czechoslovak Envoy in the United States, then in Austria, and from 1937 in Romania, Carr met with him on $24 \mathrm{Au}-$ gust. Veverka had served in Washington for eight years, from 1928 to 1936, and it is no wonder that he felt a strong bond to the United States and had been meeting American diplomats when he from time to time came from Vienna and later from Bucharest to Prague. ${ }^{14}$ Carr recorded Veverka's views very carefully. Veverka was convinced that Germany could get almost everything it wanted by patient and peaceful means, but he said that there always would exist a danger of a sudden impulse or misinformation which would trigger an armed action. Veverka said that it would be very essential to keep the territorial integrity of Czechoslovakia. He thought that Czechoslovakia should drop its current alliances and join instead the German sphere in the hope that some time in the future Czechoslovakia would manage to break away again, as it had succeeded several times in history. Veverka expressed doubts though, how the Czechoslovak public would accept such a step, particularly in view of the growing militant attitudes of the younger generation. He said that France was just a minor power and expressed doubts about its willingness to fight for the preservation of Czechoslovakia. Veverka had however little confidence in Great Britain either. Veverka's words reflected the stress, confusion, and loss of values, and the search for "saving own skin" that started to appear already from Spring 1938 and manifested iself fully after the Munich dictate, during the 2nd Republic. However, Veverka was a Czechoslovak Envoy at that time, but he spoke against the position of President Beneš and the official policy of Czechoslovakia even if he knew certainly that his every word would be reported to Washington. ${ }^{15}$

\footnotetext{
12 Karl Hermann Frank (1989-1946), a leading propagator of incorporation of Sudeten area into Germany, top official of Sudetendeutsche Partei, SS-Oberguppenführer. He kept high positions in the Protectorate Bohemia and Moravia, was responsible for brutal persecution of Czechs including extermination of Lidice. After the World War II he was sentenced to death and executed.

13 NARA, 860F.016/56.

14 Se efor example a chapter Zvláštní postup vyslance Veverky (Strange course of action of the Envoy Veverka), Polišenská, op. cit., I/2, 192-197. NARA, 860F.016/56

15 Polišenská, op. cit., I/2, 589-590.
} 
In the middle of September, the U.S. Legation in Prague informed about the increasing number of violent incidents in the Sudeten area. Carr clearly saw the real situation and repeatedly wrote, that "The Czechs continue as firm as ever in declaring they will fight rather than accept a plebiscite or secession." 16

23 September Carr reported that an abnormal peace prevailed in the country, but that Henlein's Freikorps had commited provocations and murderous assaults and that the German press and radio absolutely exaggerated and misinterpreted the incidents and threw all the guilt on the Czechs. Carr said that the facts had been often completely overturned by the German press and that there was a clear German intention to provoke problems and to make, in front of the eyes of the whole world, the Czechs responsible for them. ${ }^{17}$

A few days before the Munich conference, on 24 September, Carr analyzed indepth the current Czechoslovak situation. His report reveals his compassion with Czechoslovakia and its people, and his consternation about the tragic situation he had to witness. Carr was very strong in his statement that the bad treatment of Sudeten Germans by the Czechs was not proven by British observers nor by the investigation and research of the Legation. He reported on German propaganda, on provocations - he stated that every incident was purposedly provoked and that these provocations were supported by German offices. ${ }^{18}$

Carr had not only to make all arrangements to make the Legation safe in case of an armed conflict, but also had to provide safety and security for the approximately two thousand Americans in Czechoslovakia. He recommended that Americans leave the country. Cordell Hull at first was hesitant to approve Carr's communication to the Americans in Czechoslovakia for its possible spreading of panic, but Carr took responsibility, advised the Americans to leave the country, and as a matter of fact no panic among Americans broke out. The Legation was however flooded by an avalanche of visa applications, all kinds of inquiries including legal questions from businessmen and expressions of anxiety and fears of people. Many Czechoslovaks of importance - politicians, intellectuals, journalists, writers, artists - wanted to talk to diplomats of the very popular United States. It was very significant that it was the United States whom Czechoslovakia officially asked on 22 September 1938 for protection of its citizens and interests abroad, meaning particularly in Germany, Hungary, and Poland, and the United States accepted this task without hesitation. ${ }^{19}$

A visit by former U.S. President Herbert Hoover in Spring of 1938 was of extraordinary importance for Czechoslovak-U.S. relations. Hoover's visit to Prague was a part of his larger European trip during which he wanted to see with

\footnotetext{
16 FRUS 1938/I, 606.

17 FRUS 1938/I, 640.

18 FRUS 1938/I, 644.

19 FRUS 1938/I, 624, 625.
} 
his own eyes the situation in a region which was on the verge of war. Hoover was in Prague for three days, from 4 to 6 March 1938. Later, the Legation was commended for its careful preparation of the visit. Even though Herbert Hoover had a number of meetings and conversations with Czechoslovak politicians, diplomats, and public figures, there was no meeting of Hoover with the members of the diplomatic corps in Prague; at least there are no documents about it. This was unlike when Hoover arrived from Prague to Berlin and the American Ambassador in Germany Hugh R. Wilson organized in his honor a lunch in which the French, British, and Polish - Józef Lipski - Ambassadors took part. After his return to the United States, Hoover sent thanks and small commemorative gifts to a number of Czechoslovaks but to only four German officials. Besides Czechoslovaia and Germany, major publicity was paid to Hoover's European trip to Poland and to Finland. ${ }^{20}$

Another U.S. initiative was a short visit by the Ambassador in Berlin Hugh R. Wilson ${ }^{21}$ to Prague in August 1938. This was part of a fact-finding trip and he planned particularly to talk to Wilbur Carr. ${ }^{22}$ Actually, from Berlin he went first to Warsaw, then from Warsaw to Prague by plane at noon on Thursday 4 August, and left for Berlin the next afternoon. The Czechoslovak, Polish, and Yugoslav diplomats in Washington, D.C. learned very quickly about Wilson's trip and tried to find out from the Department of State more details. They were very eager for information but the Department of State did not have any report from Wilson, Drexel-Biddle (who was the U. S. Ambassador in Poland), or Carr yet.

Hugh Wilson was accompanied by deputy military attaché in Berlin major Arthur W. Vanaman and had his teen age son with him. Carr organized for his colleague a dinner at the Legation and invited also the British, French, and Swiss Envoys in Prague - Basil Cochran-Newton, Leopold Victor de Lacroix, and Dr. Charles Bruggmann. There was also someone from the Czechoslovak Foreign Ministry, but his name is not known.

Next day in the morning Hugh Wilson had an hour and a quarter long conversation with Czechoslovak President Edvard Beneš which Carr recorded, most likely himself, as he was present at it. Beneš provided Wilson a usual long "lecture" in which he summarized Czechoslovak-German relations from World War I and emphasized the everlasting Czechoslovak efforts to maintain good relations with Germany. Wilson was interested in the Czechoslovak-Soviet Alliance

\footnotetext{
20 Herbert Hoover Presidential Library, Post-Pres. Subject - Trips, 1938, European, Germany

21 Hugh Robert Wilson (1885-1946) was a U. S. envoy to Switzerland from 1927 to 1937, later an Assistant Secretary of State and from March to November 1938 he was a U.S. Ambassador to Germany. Later, he held several important positions in government service, taught at Yale University and wrote and published several expert books and memoirs.

22 Polišenská, op. cit, I/1, 218.
} 
Treaty from 1934 and inquired whether it was true that Germany had requested Czechoslovakia to withdraw from it. They talked also about the approaching Nazi congress in Nuremberg and on various aspects of Czechoslovak-German relations and Wilson said, that "One could not know what was in Hitler's mind. The appalling fact was that the decision as to whether there should be war or peace in Europe rested with one man.”23

Beneš was well familiar with Carr's views from personal interactions, and the Czechoslovak Envoy in Berlin Vojtěch Mastný communicated to Beneš Hugh Wilson's opinions. Now, it was an opportunity for Beneš and for Wilson to talk face to face. Wilson said that something must be done to relieve the tensions and that Beneš should not be misguided by the anti-German sentiments in the Atlantic coast of the United States where the very influential press was controlled by the Jews. Public opinion in this region did not correspond to American public opinion as a whole, Wilson said. It could be expected that Americans might express a certain degree of indignation towards Germany as well as sympathies with Czechoslovakia, but there was a great difference between such expressions and a willingness to go to war against Germany. President Beneš agreed with Wilson's views and Carr noted that he (Carr) never saw Beneš having a different opinion, even in March 1938, when in the same sense Herbert Hoover talked to him. Wilson and Beneš also discussed at length the Sudeten German issues. Beneš showed Wilson on a map that the Sudeten German plan was, from an administrative point of view, absurd and impossible and said that he welcomed the Runciman mission.

Wilson's meeting with the Foreign Minister Kamil Krofta was short and rather protocolar. After that, a lunch took place at the British Legation in honor of lord and lady Runciman as at that time the Runciman mission ${ }^{24}$ was operating in Czechoslovakia. Wilson was seated next to Runciman and they had a long conversation. Despite that, later, talking to Carr, Runciman was rather reserved about the purpose of his mission and did not suggest anything optimistic. ${ }^{25} \mathrm{Hugh}$ Wilson informed the Department of State about his observations in Warsaw and Prague, but his short visit could not provide a deeper insight into the complexity of the situation and could not be of significant addition to the information sent from Prague by Carr and from Warsaw by Anthony Drexel Biddle. Hugh Wilson

\footnotetext{
${ }^{23}$ FRUS 1938/I, 542.

24 The Runciman mission (2, 3 August-16 September 1938) was an initiative of the British government to mediate between the Sudeten Germans and the Czechoslovak Government and it was expected that it would contribute to relieving war-threatening tensions in Central Europe. The delegation was chaired by lord Runciman; a key member of the delegation was Frank AshtonGwatkin. Work of the commission and Runciman's conclusions were not objective, sided with the Sudeten Germans, and helped to implement the plans of Nazi Germany.

25 FRUS 1938/I, 542, 543.
} 
was author of several books but this trip to Warsaw and Prague on the eve of the Munich dictate does not appear in any of them. ${ }^{26}$

Lord W. Runciman and Frank Ashton-Gwatkin, who was a British diplomat and an influential member of the Runciman mission, met Carr one more time before their departure from Czechoslovakia. Carr reported to Washington that, according to Runciman, the mission was a failure, that the only positive outcome was gaining more time for negotiations, and that Ashton-Gwatkin thought that Germany did not desire any agreement with the Czechoslovak Government. ${ }^{27}$

Just three days before the Munich conference, on 26 September 1938, George Frost Kennan, a young, but experienced and skilled American diplomat assumed his position as 2 nd Secretary in Prague. ${ }^{28} \mathrm{He}$ was thirty-four years old and his previous assignments included Geneva, Hamburg, Berlin, and particularly Tallinn, Riga, Moscow, and Vienna. In his reports for the State Department and in his published memoirs From Prague after Munich: Diplomatic Papers, 1938-1940 (published 1968) and particularly in his autobiography ${ }^{29}$ he documented the situation in Czechoslovakia after Munich. It was particularly Kennan's From Prague after Munich which became a widely known testimony of the situation in Czechoslovakia, surprisingly though, never being translated into Czech.

\section{London: Joseph P. Kennedy, American Ambassador}

The American Ambassador in London was Joseph P. Kennedy, father of future American President John F. Kennedy (1961-1963). Joseph P. Kennedy's Ambassadorship in Great Britain has been subject of a number of historical studies which did not focus on Munich only, but on a larger scope of issues corresponding to the traditionally close relations of Great Britain and the United States.

Kennedy transmitted information between the Foreign Office in London and Washington, informed about opinions as he learned them at many meetings with British Prime Minister Neville Chamberlain and Secretary of State for Foreign Affairs Lord Halifax who later became British Ambassador to the United States

26 Wilson Hugh R., The Education of a Diplomat, New York: Longmans, Green and Co., 1938); Diplomat between Wars, New York: Longmans, Green and Co., 1938; A Career Diplomat: The Third Chapter, The Third Reich, New York: Vantage Press, 1960; Disarmament and the Cold War in the Thirties, New York: Vantage Press 1963; Descent into Violence - Spain, January-July 1936, Ilfracombe: Stockwell, 1969.

27 FRUS 1938/I, 605.

28 Kennan worked in Prague during the entire 2nd Republic and under the umbrella of American Consulate also shortly after the occupation and declaration of Protectorate Bohemia and Moravia.

29 Kennan, George Frost, From Prague after Munich: Diplomatic Papers, 1938-1940, Princeton: Princeton University Press, 1968; Kennan George Frost, Memoirs: 1925-1950, Boston: Little, Brown and Company, 1967. 
1940-1946. He also often met Sir Samuel Hoare, who was Secretary of State for Home Affairs.

Kennedy was informed by the Foreign Office on what instructions were received and what was reported by British Envoy in Prague Samuel Cochran Newton and British Ambassador in Berlin Arthur N. Henderson; he was updated about the developing position of the British and French Governments towards the Sudeten issue and about their changing attitudes towards the fate of Czechoslovakia. Even though Kennedy collected opinions from a large number of British public figures, particularly members of the British parliament, he did not ask questions as openly as the American Ambassador in Paris William Bullitt. ${ }^{30}$ Many memoranda of the conversations of American diplomats - Ambassador Kennedy and, in his absence, Chargé d'Affaires Johnson - with Secretary of State for Foreign Affairs Lord Halifax - testify how frequently the theme of Hitler-Czechoslovakia-France-Great Britain was discussed. Attention focused intensely also on the mission of lord Runciman in Czechoslovakia.

The appointment of Joseph P. Kennedy, Sr. as Ambassador to Great Britain finished with a serious criticism of him in both Great Britain and the United States; in expert literature it is often defined as a failure. Kennedy got the label of Nazi sympathizer, ${ }^{31}$ turn-coat, reactionary, and defender of appeasement. Kennedy was a close friend of Chamberlain and he saw the events in Austria and Czechoslovakia through "Chamberlain's eyes." Under the influence of the Munich crisis, Kennedy tried to conduct his own diplomacy and from his own initiative started talks with the German Ambassador to Great Britain Herbert von Dirksen. Kennedy told Dirksen that he would like to achieve a rapprochement and friendly relations between the United States and Germany, that most Americans including President F. D. Roosevelt were not anti-German, and commended the present German Government for achieving "great things", saying that Germany should have a free hand in the economic area in Eastern and Southeastern Europe.

Even if Kennedy proved to have certain diplomatic skills, many of his statements were risky and would complicate the situation to a large degree. He should not have taken the initiative without approval from his Secretary of State, particularly in such a critical time. In the middle of July 1938 Kennedy wrote to Roosevelt that, according to his opinion, the situation in Europe was not that critical. In the middle of August 1938 Kennedy discussed the situation repeatedly with Chamberlain and once asked the British Prime Minister if there was anything that the American President could do in this matter. Chamberlain said that there was nothing. Despite this answer and without consultation with his Government, the U. S. Ambassador expressed to Chamberlain assurances of

\footnotetext{
30 FRUS 1938/I, 621, 622.

31 A slight shade of seeing positive aspects of policies of Nazi Germany has been also associated with Ambassador in Berlin Hugh R. Wilson.
} 
Roosevelt's support and even said that President Roosevelt had decided to go ahead together with Chamberlain and would support any course which Chamberlain would choose. By this, Kennedy gave an entirely wrong impression as if Roosevelt had enthusiastically approved British steps. In the last days before Munich, Roosevelt was, on the contrary rather suspicious towards Chamberlain. Roosevelt was dissatisfied with Kennedy, who had emphasized to British journalists - and they immediately published his words - American support of the policy of appeasement. As a result, Roosevelt felt trapped by Chamberlain's politics. Hull also started to accuse Kennedy of pursuing his own politics which supported rather London than Washington. ${ }^{32}$

Kennedy became an advocate of the Munich Agreement in an effort to protect the peace; his efforts were however not consistent and often contradictory. When Kennedy in the evening of 28 September returned home from the British Parliament, he telegraphed his information to Washington. He wrote about a very positive reaction to the message of President Roosevelt, ${ }^{33}$ that many diplomats in London had spoken with him (Kennedy) in the Parliament where they came to see the newest development. Kennedy described the obvious relief and excitement and was even slightly ironical as the scene in the Parliament had seemed to him too theatrical. Kennedy said that the only dissonance in the overall positive atmosphere were the bitter words of Czechoslovak Envoy Jan Masaryk, who then joined Kennedy as they returned from the Parliament together.

\section{Paris: William Christian Bullitt, American Ambassador, and Juliusz Kukasiewicz, Polish Ambassador}

The American Ambassador in Paris was at that time William Christian Bullitt. He assumed this extraordinarily prestigious position in 1936 immediately after his previous ambassadorial assignment in Moscow finished. ${ }^{34}$ Bullitt wit-

32 Vieth, Jane Karoline, Joseph P. Kennedy and British Appeasement: The Diplomacy of a Boston Irishman, In Jones Kenneth Paul, U.S. Diplomats in Europe, 1919-1941, ABC-Clio: Santa Barbara, 1981, s. 164-182.

3326 September 1938 President Roosevelt addressed to both Hitler and Beneš a message which was the strongest American diplomatic and political initiative towards the imminent menace of confrontation in Central Europe. Beneš responded in a short factual telegram, while Hitler sent a long text accusing Czechoslovakia of bloody terror and régime of violence. Roosevelt's message had a very positive and enthusiastic response worldwide.

34 William Christian Bullitt, Jr. (1891-1967), negotiated under Woodrow Wilson with Bolshevik Russia on mutual relations; from 1933 to 1936 he was the first Ambassador of United States to the Soviet Union. Following that, he was from 1936 to 1940 the U.S. Ambassador to Paris. Later, as a result of his involvement in the conflict between Secretary of State Cordell Hull and Undersecretary Sumner Welles, he was not appointed to any other significant diplomatic post and he focused mostly on writing. FRUS 1938/I, 663-664, 669-672. 
nessed in Paris the French political attitudes towards intervention in support of Czechoslovakia in the case of aggression against the country which claimed to be France's closest ally. If Kennedy was sending from London very long telegrams, Bullitt was not far behind in this.

Bullit's reports from Paris document how French determination to keep its obligations based on the mutual treaty was mixed with worries about another major armed conflict and particularly with reluctance to be trapped in a conflict because of Czechoslovakia. Bullitt noticed how at one time French honor and noble traditions dominated, and at another reponsibility for the lives of a generation of young French men, when the devastating losses from World War I were still in fresh memory.

The diplomatic conversations became a plethora of considerations and constructions as to whether Czechoslovakia would fight or would surrender and what would happen afterwards, whether Germany would be satisfied with what it requested now and what would happen afterwards, whether the Soviet Union would move and what were its true intentions, whether Great Britain would support France, etc. Everything was interwoven with everything, the statesmen and diplomats sometimes became optimistic, sometimes closed their eyes to reality, were exhausted, overwhelmed by worries and responsibility. Even when Bullitt's reports from Paris paid attention particularly to Czechoslovakia, he always considered the global European situation. Bullitt himself saw the situation of Czechoslovakia as very black, but this was how many saw the future. For instance, Bullitt frequently also met with journalists. One of the most prominent was Walter Lippmann ${ }^{35}$ who visited Prague and was highly pessimistic about the future of Czechoslovakia. ${ }^{36}$

He had been meeting the French Minister of Foreign Affairs Georges Bonnet and the Prime Minister Edouard Daladier very often; their door was always open for him. In August and September, Bullitt saw Daladier almost daily. Daladier, who earned in the history of the Munich crisis a prominent position among appeasers, appears in the reports of American diplomats as more determined to support Czechoslovakia militarily than Bonnet.

Bonnet shared with Bullitt the newest information he received from the French Envoy in Prague, de Lacroix, from French diplomats in other European capitals, and from diplomats of other countries who were accredited in Paris, including the German Ambassador Ernst von Rath. ${ }^{37}$ Bonnett was very

\footnotetext{
35 Walter Lippmann (1889-1974), a Harvard University graduate, was an important American journalist, political commentator and writer. After the World War II he focused largely on Cold War issues and was twice awarded a Pulitzer prize (1958 and 1962).

36 FRUS 1938/I, 533.

37 Ernst von Rath was assassinated on 7 November by a young Jewish man from Poland Hercshel Grynszpan which became a pretext for the Kristallnacht.
} 
interested to know how the United States saw the dangerous situation in Central Europe and of course knew what Kennedy told in London to the French Ambassador there.

Bonnet asked whether President Roosevelt would be willing to act as an arbitrator in the Czechoslovak-German Sudeten dispute. Bullitt replied unofficially and said as his personal opinion that "I considered that this was precisely the sort of European dispute in which the United States would desire to avoid involvement. To enter into the internal arrangements of a small state in the center of Europe would certainly not appear to the American people an appropriate portion of the duties of the President of the United States". ${ }^{38}$

Bonnet told Bullitt that he worried about the position of Poland. He said that his impression was that the Poles behaved as if they did not desire anything else but the disintegration of Czechoslovakia to get the Teschen area back again. Bonnet complained that he tried to explain to the Polish Ambassador in Paris Juliusz Łukasiewicz how dangerous would be the dissolution of Czechoslovakia for Poland, but his arguments the Polish diplomat did not accept. This Polish diplomat had an extremely anti-Czechoslovak position and did not realize what a threat Nazi Germany represented to Poland. Bullitt added to this in his report that

from a source which when I was Ambassador in Moscow I always found to be the most accurate and the best informed, I received word a few days ago that the Soviet Government had prepared to the last detail a plan to march to the aid of Czechoslovakia across Poland. This source alleged that the Soviet Government had gone so far as to inquire oficially of the French Government whether the French Government would be obliged to support the Polish Government in case the Russian Army should cross Polish soil to support Czechoslovakia. ${ }^{39}$

Bullitt therefore used the opportunity and asked Bonnet whether the Soviet Government had approached him with such an inquiry and Bonnett confirmed that. Bullitt had asked for more specific details: in the case that Germany should invade Czechoslovakia - and France should then attack Germany and Polish troops should occupy the Teschen District - would France be obliged to support Poland? Bonnet said that the French Government would have no obligation to support Poland in that case. Bonnet's opinion was that if Germany should enter Czechoslovakia, the first war to break out afterwards would be between the Soviet Union and Poland, and in this Bonnet's prediction was correct. Bonnet told Bullitt next day that his major nightmare was that if the Soviet Union would try to send the army to help Czechoslovakia, that Poland and Romania would declare war on the Soviet Union. ${ }^{40}$

\footnotetext{
38 FRUS 1938/I, 531.

39 FRUS 1938/I, 555.

40 FRUS 1938/I, s. 556.
} 
Bullitt met the Polish Ambassador in Paris Juliusz Lukasiewicz from time to time. Bullitt reported on his strong anti Czechoslovak views and openly disagreed with him. ${ }^{41}$ Both diplomats had experience from serving as Ambassadors in Moscow but they did not meet there, as Bullitt was in Moscow when Łukasiewicz was already in Paris.

Bullitt described a dramatic scene when Łukasiewicz called him at noon on 25 September 1938 and asked the American diplomat to come to the Polish Embassy immediately, as he had a communication of utmost importance and that he had been working all night. Bullitt could not ignore such an urgent request and went instantly to the Polish Embassy where he found the Polish Ambassador still in his pajamas and very emotional and tense. Lukasiewicz wanted to tell Bullitt, that

until the present moment he had stated consistently that it was his conviction and that of the Polish Government that there would not be a general war in Europe. He now felt obliged to say to me that he and his Government were convinced that there would be a general war [...] that the question had become a larger one than that of Czechoslovakia. A war of religion between fascism and bolshevism was about to begin. Beneš had acted as he had because he was an agent of Moscow.

Łukasiewicz further said that

if German troops should cross the frontier of Czechoslovakia, Polish troops would cross at once and would seize not only the Teschen District but also the entire Eastern end of Slovakia in order to establish a common frontier with the Hungarians.

The Polish diplomat thought that this would mean an immediate Russian attack on Poland, but that Poland did not fear such an attack, because "within three months the Russian Armies would be in complete rout and Russia would no longer preserve even the semblance of a state but would be a hell of warring factions." Bullitt responded:

I pointed out to the Polish Ambassador that this would mean for Poland war against her ally, France. He said no, that it would mean that Poland was taking her side against Stalin and bolshevism and that France and England and, presumably later, the United States would be playing the game of Stalin in order finally to make Stalin triumphant on the Continent.

41 Juliusz Łukasiewicz (1892-1951) joined the Polish Ministry of Foreign Affairs in 1919. He specialized particularly in Eastern Europe and for five years was Head of the so called Eastern Department. He was Polish Envoy in Riga (1926-1929), Vienna (1931-1932), Moscow (1933-1936, from 1934 Ambassador) and Ambassador in Paris (1936-1939). He wrote several books. He was a strong supporter of Pilsudski's politics and a strong opponent of Sikorski. After the World War II he continued to live abroad, in 1950 emigrated to the United States and in 1951 commited suicide. 
Bullitt

said everything possible in opposition to this statement, but the Polish Ambassador remained completely unconvinced [...] and said that he had said to Bonnet that [...] the conduct of France vis-a-vis her Polish ally had been disgraceful and that he had nothing to say to the French Government and could have no further contact with the French Government unless the French Government requested it [...]. In his opinion there was no way how to save the situation except by the intervention of the Government of the United States; that we must persuade the French and British to give Poland a common frontier with Hungary and rely on Poland, Hungary and Yugoslavia to resist German advance in Eastern Europe.

Lukasiewicz insisted that Bullittt communicated this immediately to French Foreign Ministry which Bullitt did as soon as he left the Polish Embassy.

Łukasiewicz also said that it was "an absolute lie" that the French Government urged Czechoslovakia to cede the Teschen District to Poland (this Bonnet told also Bullitt the same day in the morning). Bullitt pointed out to the Polish Ambassador the ultimate consequences to Poland of war against England and France, and Lukasiewicz responded that whatever the ultimate consequences it was essential for Poland to let world know that Polish demands and policy must be respected. In the end of his report Bullitt made a remark for Hull: "I cannot see how the Czechs can accept Hitler's latest demands and I believe that unless the wounded pride and neglected interests of Poland receive at once some ointment Poland will attack Czechoslovakia immediately after Germany attacks." ${ }^{42}$

Next day, 26 September, the Polish Ambassador again asked Bullitt to see him. ${ }^{43}$ Lukasiewicz told him that he expected Bonnet to return from London "with the Teschen District on a platter as a gift for Poland". The Polish Ambassador even said that "this gift would not change the attitude of Poland. Poland did not need to have the Teschen District handed to her by France or anyone else. She could and would take the Teschen District when she wished." Lukasiewicz further developed his thoughts as "any gift of Teschen to Poland would mean something only if it were a gift, not to purchase Poland's neutrality in case of war but a gift which would be a part of the reorganization of real peace in Eastern Europe." Bullitt asked him what he meant by this idea and the Polish Ambassador replied that "it was clear that there could be no peace in Eastern Europe until Poland and Hungary had a common frontier, and Poland was encouraged by France and England to build up a bloc consisting of Poland, Hungary and Rumania to resist further German advance eastward." Bullitt quoted at this moment in his report what the Polish Military Attaché told three days earlier to the French General

\footnotetext{
42 FRUS 1938/I, 650-652.

43 FRUS 1938/I, 664.
} 
Staff - that "if German troops should attack Czechoslovakia, Polish troops at once would seize the whole of Slovakia and would give it to Hungary reserving for Poland only the Polish District of Teschen." Bullitt also quoted the Polish Ambassador who said, that

unless Poland should seize Slovakia and give it to Hungary, Germany would be able to dominate Slovakia as well as Bohemia and Moravia. It would bring intense danger to Poland to have Germany control this territory on her southern border. He could therefore see no solution of peace in Eastern Europe unless Czechoslovakia should be dismembered and the small remainder of Czechs remaining independent should be neutralized or forbidden to have any foreign policy of their own or any alliances.

Bullitt said to Lukasiewicz that "this might in his opinion be the only solution for peace in Eastern Europe, but it was not a solution which would ever be accepted by France or England or the public opinion of the world." Then the Polish diplomat added that

the Czechs had been very foolish to close not only their only frontier with Germany, but also their frontier with Poland and Hungary. As a result Czechoslovakia was hermetically sealed since transportation through the Czech-Rumanian frontier was worthless. It would not be necessary therefore to cross the frontiers of Czechoslovakia. It would only be necessary to accept the closing of the frontiers which had been the act of the Czechs and keep those frontiers completely closed whether the Czechs wished to open them or not. He said that neither Germany, Poland nor Hungary would consent to the opening of these frontiers until the Government of Czechoslovakia should have submitted absolutely to any demands. He did not think that the Czechoslovak state could continue to exist very long sealed in a bottle. $\mathrm{He}$ trusted and believed that Hitler would not precipitate war by marching across the Czech frontier. It was totally unnecessary. Czechoslovakia would die of asphyxiation and Germany, Poland, and Hungary could do what they wished with the corpse.

Bullitt interpreted what the Polish Ambassador told him without hiding his distaste. When we read these lines, we can not forget the tragic fate of Poland which was to come one year later, and we can not stop thinking about the egoism and blindness of some people of importance.

Later, Bullitt talked to the Czechoslovak Envoy in Paris Štefan Osuský. Without referring to the Polish Ambassador's remarks, he asked Osuský about the above mentioned. Osuský, who was an opponent of Edvard Beneš, admitted that Czechoslovakia at this moment "was completely cut off from contact with the outer world except by telegraph and wireless" and on Bullitt's question he responded that "he did not know how long the state can hold together." Bullitt wrote later: 
Nations continued to exist for some time under complete blockade in war and I might be sure that Czechoslovakia would resist to the bitter end. I believe that this is so; but I am as yet unable to perceive the answer to this particular argument of the Polish Ambassador.

Bullitt met afterwards also the Hungarian Envoy Sándor Khuen-Héderváry ${ }^{44}$ and reported that the conversation with him was much more satisfactory than with Łukasiewicz. The Hungarian diplomat assured Bullitt that

Hungary would not attack Czechoslovakia, but if Hungarian Government should be unable to obtain the Hungarian portion of Czechoslovakia while the Poles and Germans were receiving the portions inhabited by Germans and Poles, no Government could live in Hungary. He intimated strongly that the present Government would be driven out by the Nazi movement which would attack Czechoslovakia at once and precipitate a general war. ${ }^{45}$

\section{Conclusion}

The information activity during the Munich crisis was very hectic and the outcome was a plethora of reports. But nobody knew anything. There wasn't a lack of information, on the contrary, there was an abundance, but the most important was missing - did it really exist? Did the diplomats, ambassadors and envoys, foreign ministers and prime ministers, in the turmoil of all the visits and conversations, have time and the mental capacity to think about the issues really deeply? Didn't they get caught in the tow of their own arguments and positions, were they not too absorbed by all these meetings and conversations? This question is hard to answer.

Questions addressed to American diplomats regarding the potential American position increased as time advanced: how would the United States react in case of a German attack on Czechoslovakia, again the same questions which no one was able to answer: what would Czechoslovak President Beneš do if ..., what would Germany do if ..., what would France do if ..., what would Great Britain do if ..., the Soviet Union and other states, Poland and Hungary, could be eventually added.

Contrary to the picture of Czechoslovakia as a Masarykian democracy, there suddenly started to appear a picture of Czechoslovakia as one big problem and a threat to European security. This was a false picture, though, even if the eas-

\footnotetext{
44 Sándor Khuen-Héderváry (1881-1947), Hungarian diplomat, Hungarian envoy to France from 1934 to 1941 .

45 FRUS 1938, s. 665, 666,
} 
iest one. This can be seen from Bullitt's reports on the Polish Ambassador in Paris Juliusz Łukasiewicz.

The policy of non-involvement in European affairs and of isolationism gave the reports of the American diplomats a high degree of objectivity, even if the diplomats differed in their personal approaches toward appeasement. The reports of U.S. diplomats in Europe criticized sometimes Czechoslovakia and President Beneš in particular for their Sudeten German policies. This criticism was stronger at the beginning of Hitler's campaign, in 1935 and 1936, than in 1938 when, particularly after the annexation of Austria, Hitler's mendacious propaganda and the fifth-columns politics of SdP became obvious. However, nobody had illusions about Hitler. Remarks such as Hitler was not normal and that he was a madman appeared in the reports of American diplomats more and more frequently. Experienced, intelligent, well informed diplomats were, however, despite all the information they had, hardly able to stop the catastrophe which was approaching.

\section{Dark Future for Czechoslovakia: American and Polish Diplomats during the Munich Crisis}

\section{Summary}

The American Envoy in Prague Wilbur John Carr used for his reports a variety of sources including research in the Sudeten area. He was objective and had sincere compassion with Czechoslovakia and its people. Carr was very strong in his statement that the bad treatment of Sudeten Germans by the Czechs was not proven; he reported on Nazi propaganda and provocations supported by German offices. Former U.S. President Herbert Hoover, U.S. Ambassador in Berlin Hugh R. Wilson, the Runciman mission and many journalists visited the U.S. Legation in Prague where George Frost Kennan was assigned as a junior diplomat.

Joseph P. Kennedy was American Ambassador in London who became an advocate of Munich Agreement hoping to protect the peace, yet his efforts were often contradictory. William Christian Bullitt was American Ambassador in Paris. He wrote that French determination to keep its obligation was mixed with worries from another major armed conflict. He reported in detail on the very anti Czechoslovak position of Polish Ambassador Juliusz Lukasiewicz; among the most prominent journalist he met was Walter Lippmann who was pesimistic about the future of Czechoslovakia.

A policy of non-involvement in European affairs and of isolationism gave the reports of American diplomats a high degree of objectivity. Experienced, intelligent, well informed diplomats were, however, despite all the information they had, hardly able to stop the catastrophe which was approaching.

Key words: Munich, Crisis, Sudeten, Czechoslovakia, Poland, London, Paris, Ambassador, Envoy 


\section{Sources}

\section{Archival documents}

Foreign Relations of the United States, 1938/I, available electronically as https://uwdc. library.wisc.edu/collections/frus/

National Archive, College Park, M.D., U.S.A., 860F.00/484, 860F.00/477, 60F.00/482, 860F.00/.

\section{Literature}

Ferrell Robert Hugh, American Diplomacy: The Twentieth Century, 1999.

Kennan George Frost, From Prague after Munich: Diplomatic Papers, 1938-1940, Princeton: Princeton University Press, 1968.

Polišenská Milada, Diplomatické vztahy Československa a USA 1918-1968, Volume I/1, 1918-1938, Ministerstva, legace a diplomaté, Praha: Libri, 2012, and I/2, Priority, diplomatická praxe a politický kontext, Praha: Libri, 2014.

Wilson Hugh R., The Education of a Diplomat, New York: Longmans, Green and Co., 1938); Diplomat between Wars, New York: Longmans, Green and Co., 1938; A Career Diplomat: The Third Chapter, The Third Reich, New York: Vantage Press, 1960; Disarmament and the Cold War in the Thirties, New York: Vantage Press 1963; Descent into Violence - Spain, January-July 1936, Ilfracombe: Stockwell, 1969.

Vieth Jane Karoline, Joseph P. Kennedy and British Appeasement: The Diplomasy of a Boston Irishman, in Jones, Kenneth Paul, U.S. Diplomats in Europe, 19191941, ABC-Clio: Santa Barbara, 1981, s. 164-182. 